\title{
PENDAMPINGAN PENGELOLAAN KEUANGAN GUNA MENINGKATKAN PENDAPATAN KELUARGA DI DUSUN PONGGANG
}

\author{
Riana Magdalena ${ }^{1}$, Wibawa Prasetya ${ }^{2}$ \\ ${ }^{1}$ Program Studi Teknik Industri,Universitas Katolik Indonesia Atma Jaya \\ Jalan Raya Cisauk Lapan No. 10, Sampora, Cisauk, Tangerang, Banten 15345 \\ ${ }^{2}$ Program Studi Teknik Industri, Universitas Katolik Indonesia Atma Jaya \\ Jalan Raya Cisauk Lapan No. 10, Sampora, Cisauk, Tangerang, Banten 15345 \\ Email :riana.magdalena@ atmajaya.ac.id ${ }^{1}$,wibawaprasetya20@ gmail.com ${ }^{2}$
}

\begin{abstract}
ABSTRAK
Sistem pengelolaan keuangan usaha merupakan hal penting di dalam memajukan UMKM Dusun Ponggang. Dalam pelaksanaannya, ibu-ibu pelaku UMKM di Dusun Ponggang sering menghadapi kendala ketika akan membuat laporan pertanggung jawaban dalam bentuk laporan keuangan bulanan maupun tahunan. Sedangkan apabila harus menyerahkan pembuatan laporan keuangan kepada pihak luar diperlukan biaya yang tidak sedikit Oleh karena itu kegiatan pegabdian kepada masyarakat ini bertujuan untuk mentransfer pengetahuan dan teknik pembuatan laporan keuangan sederhana pada ibu-ibu pelaku UMKM Dusun Ponggang dapat mandiri dalam pembuatan laporan keuangannya. Adapun metode yang dilakukan berupa penyampian materi dan praktik/penerapan pembuatan laporan keuangan. Hasil kegiatan menunjukkan bahwa sebelum pelaksanaan PKM Ibu -Ibu pelaku UMKM Dusun Ponggang kurang menguasai mengenai laporan keuangan sederhana, namun setelah pelaksaan kegiatan diketahui Ibu-Ibu pelaku UMKM Dusun Ponggang cukup menguasai dan dapat membuat laporan keuangan sederhana. Kegiatan PKM secara tidak langsung sangat berperan positif dalam meningkatkan pengetahuan peserta dan keterampilan peserta dalam pembuatan laporan keuangan sederhana.Oleh karena itu, pelatihan dan pendampingan Laporan Keuangan yang baik penting untuk dilakukan secara berkelanjutan supaya anggota UMKM Dusun Ponggang dapat semakin maju usahanya.
\end{abstract}

Kata kunci : Ponggang, Laporan Keuangan

\section{PENDAHULUAN}

Pengabdian Kepada Masyarakat merupakan suatu media untuk menjembatani dunia pendidikan dengan masayarakat, dimana Perguruan Tinggi dihadapkan pada masalah bagaimana agar warga masyarakat mampu menghadapi tantangan lebih jauh ke depan di era globalisasi. Berdasarkan hasil statistik di Tahun 2015 di Kecamatan Serangpanjang Subang ditemukan dari 8139 KK terdapat 5513 KK yang masuk dalam kategori belum sejahtera (BPS, 2015). Salah satu dusun yang terletak di Kecamatan Serangpanjang adalah Dusun Ponggang.

Dusun Ponggang merupakan sebuah daerah yang berbukit dan memiliki sumber air yang berada di bawah daerah pemukiman warga. Lokasi Dusun Ponggang berada di wilayah Kecamatan Serangpanjang, Kabupaten Subang, seperti yang ditunjukkan pada gambar 1. Masyarakat Dusun Ponggang masih menjunjung tinggi nilai-nilai adat yang ditanamkan oleh leluhur mereka. Sebagai contoh, pada saat akan memulai masa tanam padi, masyarakat Dusun Ponggang mengadakan ritual "ngaruat" dan doa-doa kepada leluhur.

Dusun Ponggang dihuni oleh \pm 70 kepala keluarga dengan tingkat pendidikan yang masih tergolong rendah dengan mayoritas mata pencaharian di bidang pertanian. Mata pencaharian utama para penduduk di Dusun Ponggang adalah bertani. Rata-rata penduduknya masih menggantungkan kebutuhan sehari-hari mereka dari hasil pertanian.

Universitas Katolik Indonesia Atma Jaya, khususnya Fakultas Teknik, sebagai institusi pendidikan tinggi yang mengemban Tri Dharma Perguruan Tinggi, telah menjalin kerja sama sejak 2013 bersama masyarakat Dusun Ponggang sebagai bagian dari Program Pengabdian Masyarakat, seperti terlihat di 
gambar 1 dan gambar 2 dibawah ini. Bentuk kerjasama yang sudah dilakukan antara lain melalui pelatihan dan pendampingan wirausaha bagi penghuni Dusun Ponggang dengan usaha pertama adalah keripik Singkong. Bahan-bahan dasar pembuatan produk ini mudah diperoleh karena masih banyak dijumpai di Dusun Ponggang.

Pada tahun 2016, Tim Pengabdian Masyarakat dari Prodi Teknik Industri mendapatkan Hibah Dikti untuk pengabdian masyarakat dalam mengembangkan wirausaha keripik singkong oleh warga di Dusun Ponggang. Hasil dari hibah tersebut antara lain telah dilakukan renovasi dapur usaha yang menjadi tempat produksi sebagai syarat untuk memperoleh sertifikat P-IRT (Produk-Industri Rumah Tangga). Sertifikat P-IRT merupakan izin yang dibutuhkan oleh UKM atau home industry untuk dapat menjual produknya secara legal. Setelah melalui serangkaian tahapan dan persyaratan, akhirnya wirausaha keripik singkong oleh warga di Dusun Ponggang telah memperoleh sertifikat P-IRT dari Dinas Kesehatan Kabupaten Subang dengan P-IRT No 2153213010784-22.

Melalui pendampingan dan pelatihan kewirausahaan ini diperoleh manfaat antara lain: menyerap lebih banyak tenaga kerja perempuan sehingga mengurangi tingkat pengangguran di dusun tersebut, serta terbentuknya produk unggulan keripik singkong Dusun Ponggang yang disebut Pong's yang diharapkan dapat menyejahterakan masyarakat di Dusun Ponggang.

Berdasarkan wawancara terhadap ibu-ibu pelaku UMKM Dusun Ponggang yang bertugas membuat laporan keuangan ditemukan bahwa salah satu penyebab kesulitan dalam pembuatan laporan keuangan disebabkan dasar pendidikan yang tidak memiliki kompetensi di bidang laporan keuangan.

Melihat kenyataan perlu dan mendesaknya kebutuhan akan keterampilan membuat laporan keuangan, maka dirasa perlu adanya pelatihan pembuatan laporan keuangan sedarhana bagi Ibu-ibu di Dusun guna meningkatkan kompetensi dan pemahaman mengenai tata cara pembuatan laporan sederhana yang pada akhirnya diharapkan Ibu-ibu Dusun Ponggang nantinya dapat membuat laporan keuangan mandiri.

\section{TINJAUAN PUSTAKA}

Pada sistem manajemen modern, suatu metoda yang popular yaitu PDCA (Plan-Do-CheckAction / Rencanakan-Kerjakan-Periksa-Tindaklanjuti), digunakan untuk melakukan perbaikan berkelanjutan (continuous improvement) pada suatu organisasi. Intisari dari PDCA merupakan suatu proses iterasi (berulang), sekali suatu rencana telah ditetapkan sebelumnya, maka rencana berikutnya ditetapkan berdasarkan hasil dari rencana sebelumnya. Apakah hasilnya dapat dicapai (pencapaian yang benar) ataupun tidak dapat dicapai (pencapaian yang salah). Hasil yang positif akan menjadi standard pembanding / acuan bagi pencapaian berikutnya. Program pengabdian masyarakat yang dilakukan di Dusun Ponggang ini dilaksanakan dalam tiga kurun waktu yang berbeda. Kegiatan pertama yang dilaksanakan pada bulan Desember 2017 dan dilanjutkan pada Maret 2018. Pada 2 kegiatan terdahulu merupakan bagian dari langkah Plan dan Do sesuai dalam siklus PDCA. Pada kunjungan ketiga yang dilakukan pada bulan September 2018 ini dilakukan langkah ketiga dan langkah keempat dari rangkaian metode PDCA ini yaitu langkah Check dan Act.

Metode Plan-Do-Check-Act (PDCA) merupakan suatu siklus penyelesaian masalah yang sistematis yang pada saat ini sudah banyak diaplikasikan di perusahan besar di Indonesia, namun sudah lama diterapkan di negara-negara maju seperti Jepang, German, USA. Untuk dapat mngeimplementasikan PDCA dalam konteks semangat perbaikan yang berkesinambungan untuk meningkatkan mutu organisasi, tidak hanya memerlukan pemahaman tentang konsep PDCA itu sendiri, tetapi juga memerlukan pemahaman akan pengetahuan dan keterampilan dalam penggunaan alat-alat 
manajemen kualitas. Bagaimanapun implementasi dari setiap tahap PDCA, mulai dari tahap P (Plan) sampai A (Act) memerlukan seperangkat alat bantu yang dapat digunakan untuk mengefektifkan tindakan dalam setiap tahapan. Kaitan antara setiap tahapan dalam PDCA dan seperangkatan alat kualitas dapat dilihat pada gambar.

Dalam penerapan PDCA untuk menyelesaikan sebuah masalah, maka proses dilakukan sesuai dengan arah jarum jam dimulai dari proses Plan - Do - Check - Act, kemudian siklus akan terus berulang untuk terus mempebaharui dan menyempurnakan cara penyelesaian permasalahan yang ada, beberapa rincian dari setiap tahap PDCA dapat dilihat pada gambar dibawah ini.

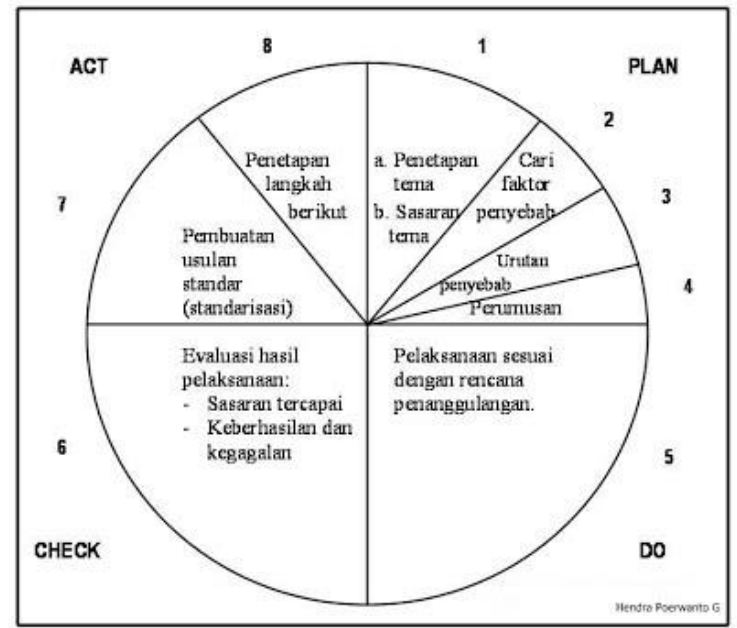

Gambar 1. Diagram Rincian Metode PDCA

Sumber : https://sites.google.com/site/kelolakualitas/PDCA/Implementasi-Plan-Do-Check-Act-PDCA

Pada tahap Plan, ada empat hal yang harus dilakukan dalam implementasinya yakni Penetapan tema dan sasaran tema, mencari faktor penyebab, urutan penyebab, dan perumusan. Artinya PDCA tahap ini diimplementasikan dalam bentuk tindakan menentukan proses mana yang perlu diperbaiki dan perbaikan apa yang perlu dilakukan serta bagaimana melakukannya. Pendek kata, pada tahap ini, disusun rencana yang akan dilakukan, atau menentukan masalah yang akan diatasi atau kelemahan yang akan diperbaiki dan mencari solusi untuk mengatasi masalah tersebut. Menjadi kewajiban pimpinan organisasi untuk menentukan data dan informasi yang diperlukan agar dapat memilih hipotesis mana yang paling relevan untuk melakukan perbaikan proses. Pendek kata, pada tahap "perencanaan" pimpinan menyusun, merencanakan, mengkoordinasikan, mensosialisasikan, dan mengkomunikasikan tema atau persoalan inti yang hendah diselesaikan. Pada tahap ini diperlukan alat kualitas untuk membantu mengidentifikasi masalah, dan menyusun rencana perbaikan seperti misalnya pemetaan layanan pelanggan, flowchart, analisis pareto, brainstorming, teknik diskusi kelompok, analisis pohon, matriks evaluasi, diagram sebab akibat (fishbone)

Implementasi pada tahap Do dijalankan dengan mengerjakan apa yang telah direncanakan dan memantau proses pelaksanaannya. Pada tahap ini, ambilah keputusan berdasarkan tahapan Plan, dimana anda akan melihat problem-problem yang mempunyai pengaruh yang sangat besar terhadap proses atau project yang anda kerjakan. Fokuskan perbaikan atau solusi terhadap masalah terbesar saja (mungkin hanya terdapat 2 atau 3 masalah utama yang mempunyai pengaruh sangat besar). Alatalat kualitas yang biasa digunakan untuk membantu implementasi tahap ini antara lain keterampilan memimpin kelompok kecil, desain eksperimen, resolusi konflik, dan pelatihan sambil kerja.

Tahap Check diimplementasikan dengan mengawasi proses "mengerjakan" dan mengumpulkan baseline information untuk menentukan keadaan nyata sekarang mengenai jalannya proses apakah 
hasil yang terjadi sesuai dengan perencanaan. Meneliti apa yang telah dilaksanakan dan menemukan kelemahan-kelemahan yang perlu diperbaiki. Berdasarkan kelemahan-kelemahan tersebut disusun rencana perbaikan untuk dilaksanakan selanjutnya. Dengan kata lain, tahap "pengecekan" diimplementasikan dengan melakukan evaluasi terhadap hasil pelaksanaan. Pada tahap ini dilakukan evaluasi terhadap perubahan atau perbaikan terhadap proses yang telah dilakukan. Kemudian harus dipelajari, seberapa efektifkah dan seberapa besar pengaruhnya langkah perbaikan tersebut terhadap proses tersebut. Pimpinan organisasi memeriksa, memonitor, mengecek, mengukur, mengevaluasi segala hal yang dikerjakan pada tahap "mengerjakan". Ada tiga kemungkinan hasil yang dapat diamati dari implementasi tahap pengecekan antara lain :

- Hasilnya bermutu sesuai yang direncanakan, sehingga prosedur bersangkutan dapat dipergunakan di masa mendatang.

- Hasilnya tak bermutu, tidak sesuai yang direncanakan sehingga prosedur yang bersangutan tersebut tidak sesuai dan harus diganti atau diperbaiki di masa mendatang.

- Prosedur yang bersangkutan mungkin dapat dipakai untuk keadaan berbeda.

Dengan demikian, proses sesungguhnya tidak berakhir pada langkah Act, tetapi kembali lagi pada langkah pertama dan seterusnya. Beberapa alat kualitas yang digunakan dalam implementasi tahap ini antara lain Check sheet, analisis grafik, control chart, indikator kinerja kunci.

Tahap Act diimplementasikan dengan membuat usulan standard dan menetapkan langkah selanjutnya berdasarkan temuan dari tahap Check. Implementasi tahap ini dimaksudkan untuk menjawab bagaimana tindak lanjut untuk menjadi lebih baik di kemudian hari dan melaksanakan keseluruhan rencana peningkatan perbaikan, termasuk perbaikan kelemahan-kelemahan yang telah ditemukan.

Pada tahap ini ada kemungkinan dilakukan standarisasi ulang proses dan persiapan terhadap perbaikan berikutnya. Pada tahap ini, proses perbaikan yang terbaik efeknya akan digunakan/diterapkan dalam proses selanjutnya dan selalu dimonitoring, kemudian distandarisasi sebagai suatu prosedur standar. Setelah proses/ proyek mengalami perubahan baik dan stabil maka segera lakukan persiapan lagi untuk melakukan perbaikan yang lebih baik lagi. Dan begitu seterusnya.

Pimpinan melaporkan, mempertanggungjawabkan, menindaklanjuti, memperbaiki, dan meningkatkan performansi. Lebih dari itu, pimpinan memutuskan perubahan yang akan diimplementasikan; bila berhasil, perlu disusun prosedur yang baku. Memutuskan sejauh mana perlu pelatihan ulang dan tambahan bagi karyawan terkait serta mengkaji perubahan tersebut punya efek negatif terhadap bagian lain organisasi atau tidak. Selanjutnya, memantau terus perubahan tersebut. Implementasi tahap ini memerlukan seperangkat alat bantu seperti pemetaan proses, standardisasi proses, informasi pengendalian, pelatihan formal untuk kepentingan standardisasi proses.

\section{METODOLOGI}

Metode yang dilakukan dalam kegiatan pengabdian kepada masyarakat ini dilakukan dengan melakukan pelatihan dan pendampingan dalam proses penyampaian pengetahuan mengenai pembuatan laporan keuangan sederhana kepada Ibu-ibu pelaku UMKM Dusun Ponggang sehingga peserta pengabdian dapat mengetahui tata cara pembuatan laporan keuangan sederhana bagi organisasi yang dilanjutkan dengan pelatihan pembuatannya secara langsung.

Program pengabdian masyarakat yang dilakukan di Dusun Ponggang ini dilaksanakan dalam dua kurun waktu yang berbeda. Kegiatan pertama yang dilaksanakan pada bulan Desember 2017 dan dilanjutkan pada Maret 2018. Pada 2 kegiatan terdahulu merupakan bagian dari langkah Plan dan Do sesuai dalam siklus PDCA. Pada kunjungan ketiga yang dilakukan pada bulan September 2018 ini 
dilakukan langkah ketiga dan langkah keempat dari rangkaian metode PDCA ini yaitu langkah Check dan Act.

\subsection{Penyampaian Pengetahuan Mengenai Pembuatan Laporan Keuangan Sederhana}

Langkah awal metode pelaksanaan kegiatan pengabdian ini yaitu penyampaian pengetahuan mengenai pembuatan laporan keuangan sederhana pada Ibu-Ibu pelaku UMKM Dusun Ponggang. Kegiatan ini dilaksanakan pada tanggal 4-5 Desember 2018. Kegiatan ini dilakukan dengan tatap muka secara langsung yang disertai diskusi dan tanya jawab mengenai materi yang disampaikan. Adapun materi yang disampaian mengenai pembuatan laporan keuangan sederhana yang meliputi:

1) Analisis Neraca

Analisis neraca keuangan ditujukan untuk mengetahui posisi keuangan dari organisasi dalam hal ini UMKM milik Ibu-ibu Dusun Ponggang pada suatu periode tertentu. Neraca merupakan bagian dari laporan keuangan yang dibuat setahun sekali. Neraca memiliki beberapa unsur yang secara garis besar dapat dibagi menjadi tiga meliputi harta, kewajiban dan modal. Melalui analisis neraca ini juga akan bermanfaat bagi peserta sehingga dapat membedakan antaraa harta, kewajiban maupun modal (Hanafi, 2007).

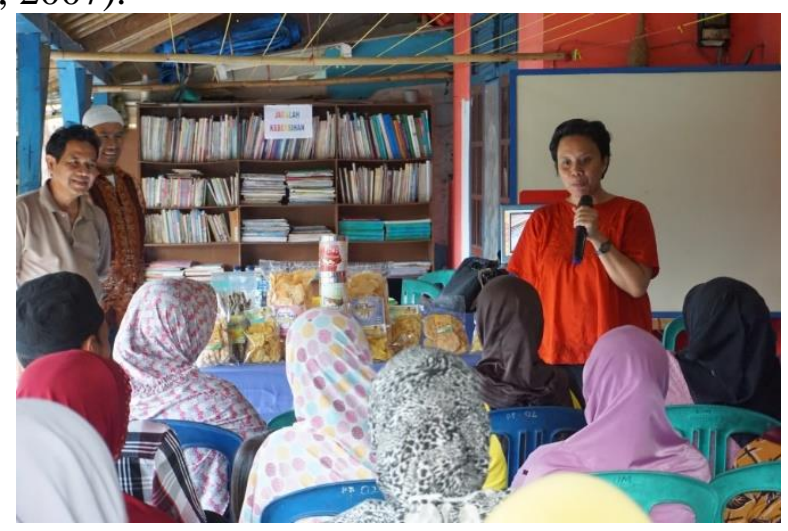

Gambar 2. Proses Penyampaian Materi dari Tim Pemateri PKM Pada Kunjungan

Pertama Tanggal 4-5 Desember 2017

2) Analisis Laporan Laba Rugi

Menurut Kasmir (2012) Analisis Laporan laba rugi merupakan analisis yang memuat laporan tentang selisih pendapatan setelah dikurangi dengan biaya-biaya atau beban. Analisis Laporan Laba Rugi dapat bermanfaat bagi peserta untuk mengambil kebijakan atau sebagai dasar ukuran seperti untuk mengukur tingkat pengembalian dari investasi kegiatan.

3) Analisis Laporan Arus Kas

Laporan arus kas memuat segala informasi yang berhubungan dengan kas masuk dan kas keluar dalam periode yang telah ditetapkan. Analisis ini sangat bermanfaat bagi peserta terutama sebagai catatan historis atas pengeluaran atau pemasukan yang berhubungan dengan kas (Sucipto, 2013).

Di akhir pelatihan pada bulan Desember 2018, diadakan pre-test untuk mengetahui sejauh mana peserta pengabdian mengerti dan menyerap materi yang diberikan. Dan dibuat rencana untuk membuat laporan keuangan sederhana selama 3 bulan kedepan.

Untuk mendampingi peserta pengabdian dibuat sebuah whatsApp grup sebagai wadah interaktif untuk berkomunikasi antara Tim Pemateri dan Ibu-ibu pelaku UMKM mengenai masalah dan perkembangan yang dihadapi dalam melaksanakan pembuatan laporan keuangan sederhana. 


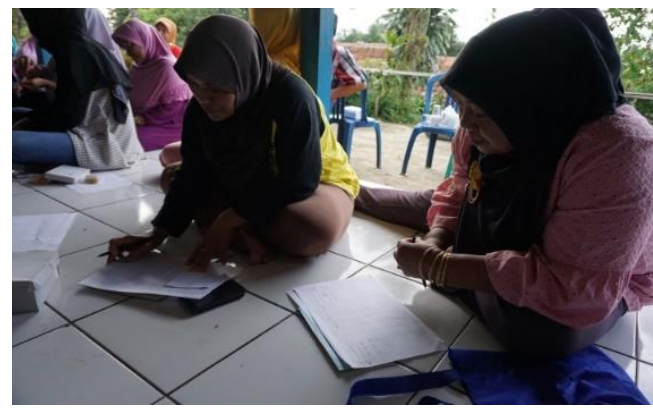

Gambar 3. Pelaksanaan Pre Test

\subsection{Penerapan Pembuatan Laporan Keuangan Sederhana}

Penerapan pembuatan laporan keuangan sederhana dilakukan dengan metode aplikatif yaitu seluruh peserta diberikan kesempatan untuk melakukan pembukuan sederhana selama 3 bulan dari Desember 2017 - Maret 2018. Selama periode tersebut setiap data pengeluaran, pemasukan, harta dan kewajiban dari laporan keuangan yang ada harus dikelompokkan pada buku yang telah disediakan yaitu meliputi : Buku kas, persediaan barang, pembelian barang, penjualan, biaya, piutang maupun buku hutang. Setelah dikelompokkan secara benar, masing-masing peserta diminta untuk menyusunnya kedalam laporan keuangan (laporan laba rugi dan neraca).

Pada kunjungan di bulan Maret 2018, ditemukan Ibu-ibu pelaku UMKM Dusun Ponggang, belum melaksanakan pembukuan sederhana secara konsisten, sehingga dirasa perlu diberikan tambahan waktu untuk mendampingi Ibu-ibu pelaku UMKM Dusun Ponggang agar dapat menyusun pembukuan sederhana secara baik dan benar. Dan pada kunjungan ketiga di bulan September 2018, Tim Pemateri kembali mengunjungi Dusun Ponggang untuk memeriksa penyusunan pembukuan Ibuibu pelaku UMKM Ponggang dan menggali dengan lebih detail masalah yang dialami serta kemajuan apa yang telah dicapai.

\subsection{Tahapan Kegiatan Pengabdian}

Kegiatan pengabdian kepada masyarakat ini dimulai dengan melakukan analisis situasi dan koordinasi dengan objek pengbdian kepada masyarakat, yang dilanjutkan dengan kegiatan inti yang meliputi penyampaian materi mengenai Pengetahuan Pembuan Sederhana dan Penerapan Pembuatan Laporan Keuangan Sederhana yang kemudian diakhiri dengan kegiatan akhir yaitu evaluasi program. Untuk lebih jelasnya, Tahapan kegiatan PKM ini dapat dijelaskan melalui Gambar 4. berikut ini :

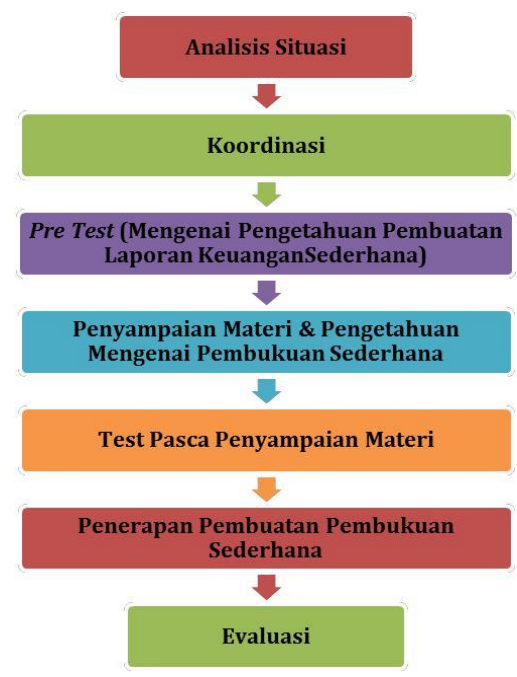

Gambar 4. Tahapan Kegiatan Pengabdian 


\section{HASIL PENELITIAN}

Keberhasilan kegiatan pengabdian kepada masyarakat salah satunya dapat dilihat dari hasil evaluasi apakah terjadi perbaikan dari peserta pengabdian setelah dilakukan kegiatan. Hasil kegiatan PKM ini dapat dijelaskan sebagai berikut :

\subsection{Pengetahuan Peserta Mengenai Pembuatan Laporan Keuangan Sederhana Sebelum disampaikan Materi}

Berdasarkan hasil pre test (tes pendahuluan) sebelum dilakukan penyampaian materi mengenai pembuatan laporan keuangan sederhana diketahui bahwa pengetahuan peserta dalam hal ini Ibu-Ibu PKK Dusun Ponggang Serangpanjang Subang mayoritas berada di kategori kurang menguasai materi yaitu sebanyak $72,72 \%$ atau sebanyak 20 orang, sedangkan yang cukup menguasai hanya 2 orang $(18,18 \%)$. Hasil pre test juga menunjukkan bahwa materi mengenai neraca yang sebenarnya merupakan dasar dari pembuatan laporan keuangan sederhana kurang dikuasai oleh peserta.

\subsection{Pengetahuan Peserta (Ibu-Ibu PKK Dusun Ponggang) Mengenai Pembuatan LaporanKeuangan Sederhana Setelah disampaikan Materi}

Test mengenai pengetahuan peserta dalam hal ini Ibu-ibu pelaku UMKM Dusun Ponggang mengenai laporan keuangan sederhana setelah disampaikan materi sangat diperlukan untuk mengukur keberhasilan kegiatan penyampaian materi mengenai laporan kaunagan sederhana oleh tim pengabdian.

Berdasarkan hasil test pasca penyampaian materi diketahui bahwa pengetahuan peserta mengenai laporan keuangan sederhana setelah disampaikan materi mayoritas berada pada kategori cukup menguasai $77,27 \%$ atau 17 orang, 13,63\% atau 3 orang berada pada kategori menguasai, 9,09\% atau 2 orang sangat menguasai materi.

\section{DISKUSI}

Hasil ini juga menunjukkan bahwa terdapat perbedaan yang cukup signifikan antara hasil sebelum dan sesudah kegiatan penyampaian materi. Hal mengindikasikan kegiatan PKM dalam hal ini penyampian materi mengenai laporan keuangan sederhana dapat dikatakan berhasil meningkatkan pengetahuan peserta.

Setelah dilakukan penyampaian materi dan test pasca penyampaian materi, peserta diarahkan untuk membuat laporan keuangan sederhana, hasilnya sebagian besar peserta telah mampu membuat laporan keuangan sederhana seperti laporan laba rugi, perubahan ekuitas dan arus kas. Namun untuk neraca, diketahui bahwa sebagian peserta cukup mengalami kesulitan, hal ini mayoritas disebabkan oleh kurangnya ketelitian peserta sehingga umumnya laporan neraca yang dibuat tidak seimbang (unbalanced). Namun secara umum dapat disimpulkan bahwa Peserta telah mampu baik untuk membuat laporan keuangan sederhana baik secara personal maupun secara berkelompok.

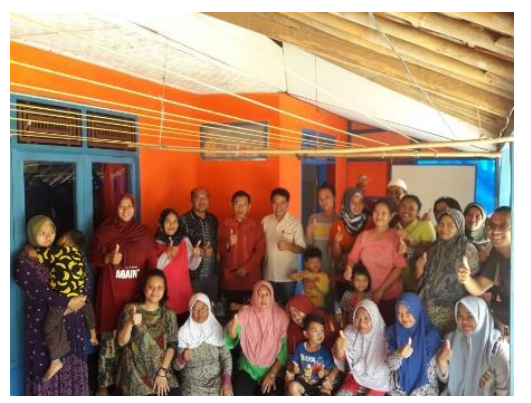

Gambar 5. Foto Bersama Pasca Pelaksanaan Kegiatan PKM 


\section{KESIMPULAN}

Berdasarkan kegiatan PKM yang telah dilaksanakan dapat ditarik beberapa kesimpulan antara lain sebagai berikut :

1) Pengetahuan peserta dalam hal ini Ibu-Ibu pelaku UMKM Dusun Ponggang mengenai laporan keuangan sederhana sebelum kegiatan PKM mayoritas berada di kategori kurang menguasai materi yaitu sebanyak $72,72 \%$.

2) Setelah kegiatan PKM diketahui bahwa pengetahuan peserta mengenai laporan keuangan sederhana setelah disampaikan materi mayoritas berada pada kategori cukup menguasai $(77,27 \%)$

3) Sebagian besar peserta pasca kegiatan PKM telah mampu membuat laporan keuangan sederhana seperti laporan laba rugi dan arus kas. Namun untuk neraca, diketahui bahwa sebagian peserta cukup mengalami kesulitan,

4) Dapat disimpulkan juga bahwa terjadi peningkatan pengetahuan dan keterampilan peserta dalam hal pembuatan laporan keuangan sederhana pasca kegiatan ini.

\section{DAFTAR PUSTAKA}

https://subangkab.bps.go.id/statictable/2015/09/24/54/jumlah-keluarga-menurut-tingkat-

kesejahteraan-di-kabupaten-subang-tahun-2013.html

Hanafi, Mamduh M dan Halim, Abdul. 2007. Analisis Laporan Keuangan Edisi Ketiga. STIE YKPN.Yogyakarta.

Kasmir. 2012. Analisis Laporan Keuangan. PT. Raja Grafindo Persada. Jakarta

Sucipto. 2003. Penilaian Kinerja Keuangan. Jurnal Akuntansi. Program Sarjana Universitas Sumatera Utara. Medan. 